\title{
Immune response to flour and dust mites in a United Kingdom bakery
}

\author{
R D Tee, D J Gordon, S Gordon, B Crook, A J Nunn, A W Musk, K M Venables, \\ A J Newman Taylor
}

\begin{abstract}
In a study of 279 United Kingdom bakery workers a high prevalence of immunological response to storage mites was found. To determine whether this was the consequence of exposure to storage mites in bakery work, a population of salt packing workers was examined as a comparison group not at occupational risk of exposure to storage mites. Forty two per cent of both groups were atopic (had a positive skin prick response greater than negative controls to $D$ pteronyssinus, grass pollen, or cat fur by $2 \mathrm{~mm}$ or more) and $33 \%$ had an immediate skin prick test response to at least one of four storage mites ( $L$ destructor, Gdomesticus, $T$ putrescentiae, A Siro). A higher percentage of the salt packing workers than the bakery workers had a positive radioallergosorbent test (RAST) ( $\geqslant 0.35$ PRU) to $D$ pteronyssinus and to the four storage mites. Logistic regression analysis identified atopy as the most significant variable for a positive skin test and RAST response to storage mites in both groups of workers. RAST inhibition was used to analyse extracted area and personal air samples. Analysis of static area
\end{abstract}

Department of Occupational and Environmental Medicine, National Heart and Lung Institute, Royal Brompton Hospital, London SW3 6LR

R D Tee, D J Gordon, S Gordon, A W Musk, K M Venables, A J Newman Taylor

MRC Cardiothoracic Epidemiology Group, Brompton Hospital, London SW3 6HP

A J Nunn

AFRC Institute of Arable Crops Research, Rothamstead Experimental Station, Harpenden, Herts.

B Crook

Present addresses: Occupational Medicine and Hygiene Laboratories, Health and Safety Executive, London NW2 6LN

B Crook

Virus Research Institute, PO Box 49, Entebbe, Uganda

A J Nunn

Sir Charles Gairdner Hospital, Nedlands, Western Australia

A W Musk samples for aeroallergen showed immunological identity with flour but $L$ destructor was found in only one of seven exposed filters. The concentration of airborne flour was related to exposure rank of perceived dustiness and gravimetric measurement of total dust. Nineteen out of 32 filters from workers in jobs with higher dust exposure (rank $\geqslant 6$ ) had a level of $>10 \mu \mathrm{g} / \mathrm{m}^{3}$ flour whereas this concentration was exceeded in only one of 23 filters from workers in low dust exposure ( $<$ rank 6 ). It is concluded that storage mites are not of special significance in allergic responses in bakery workers. The development of immunological (and airway) responsiveness to inhaled flour dust is increased in those exposed to higher concentrations of airborne allergen, which appears to be predominantly flour and not storage mites.

Occupational asthma is common in those exposed to flour and grain. ${ }^{1-4}$ Possible explanations for this are the development of hypersensitivity reactions to proteins in the flour and grain themselves, ${ }^{5}$ or to moulds ${ }^{6}$ and mites $^{7}$ in the flour and grain when stored.

In our study of a modern UK bakery ${ }^{8}$ a third of the workers were found to have a skin prick test response to one or more storage mites that was related to current or past exposure to dust. In this part of the study we have examined immunological reactivity to flour and storage mites in more detail. We compared IgE and skin prick test responses to storage mites in bakers with those in salt packing factory workers without exposure to flour, and also examined air samples from the bakery for storage mite and flour allergens.

\section{Methods}

SUBJECTS

Of the 318 current employees of the bakery, 279 $(88 \%)$ were studied. They completed a questionnaire and had spirometry, bronchial reactivity tests and skin prick tests. ${ }^{8}$ The workers also gave blood for measurements of specific IgE antibodies and a proportion of them wore personal air sampling pumps to allow exposure to dust and allergen to be estimated. 
Eighty two $(77 \%)$ of 107 current employees in the salt packing factory were studied. These workers completed a questionnaire, had skin prick tests, and gave blood.

\section{SKIN PRICK TESTING}

A total of $251(80 \%)$ of the bakery workers and 65 $(61 \%)$ of the salt packing workers had skin prick tests with extracts of B2 grass pollens (4100 Bencard, Brentford, Middlesex), D pteronyssinus (2801, Bencard), and cat fur (3204, Bencard). We defined atopy as the presence of a positive skin prick test $(\geqslant 2 \mathrm{~mm}$ wheal) to one or more of these three commercial extracts. Also, all workers were tested with wheat grain (5101, Bencard), mixed flour (5105, Bencard), Tyrophagus longior $(5 \mathrm{mg} / \mathrm{ml}$; Health and Safety Executive (HSE), London), Acarus siro $(5 \mathrm{mg} / \mathrm{ml}$; HSE), Lepidoglyphus destructor ( $5 \mathrm{mg} / \mathrm{ml}$; HSE), Tyrophagus putrescentiae $(5 \mathrm{mg} / \mathrm{ml}, 78 / 517$; National Institute of Biological Standards and Control (NIBSC)). The salt packers were not skin prick tested with this NIBSC antigen but were additionally tested with $A$ siro, $L$ destructor, and $T$ putrescentiae supplied by ALK, Copenhagen, Denmark. The positive control was $1 \%$ histamine dihydrogen chloride and the negative control was $50 \%$ Coca's solution: $50 \%$ glycerol. A positive skin test was taken as a $2 \mathrm{~mm}$ wheal greater than that to the negative control solution.

\section{RADIOALLERGOSORBENT ASSAY (RAST)}

Measurement of specific IgE antibodies was made on $244(77 \%)$ of the bakery workers and $66(62 \%)$ of the salt packing workers. Serum samples were tested with the commercial allergen discs (Pharmacia, Uppsala, Sweden) $D$ pteronyssinus (d1), $L$ destructor (d71), $A$ siro (d70), $T$ putrescentiae (d72), $G$ domesticus (d73), wheat (f4), and a non-commercial flour mix of the three main flours used in the bakerynamely, mixed flour (Brompton Hospital (BH)). The three flours were extracted in Coca's solution and equal quantities of each lyophilised extract coupled to cyanogen bromide activated paper discs as described previously. ${ }^{9}$

\section{RAST assay}

Fifty microlitres of serum per disc were incubated for 16 hours at room temperature. After washing, $50 \mu \mathrm{l}$ ${ }^{125}$ I anti-IgE (Pharmacia) was added to each tube for a second 16 hour incubation. After further washing, the tubes were counted in a $\gamma$-counter. The Phadebas RAST reference system (Pharmacia Diagnostics AB) was included in all assays, which allowed expression of results in Phadebas RAST units (PRU) and therefore comparison of RAST binding between assays and with other centres. A positive RAST response was defined as $\geqslant 0.35$ PRU.

\section{RAST INHIBITION}

$L$ destructor was chosen as the storage mite to be estimated in the atmosphere of the bakery because previous RAST inhibition studies ${ }^{10}$ showed that it had the least shared allergens with $D$ pteronyssinus compared with the other dust mites. RAST inhibition was performed by a 16 hour preincubation of a pool of positive sera $(100 \mu \mathrm{l})$ with $100 \mu \mathrm{l}$ of 10 -fold concentrations $(1 \mu \mathrm{g}$ to $100 \mathrm{mg} / \mathrm{ml})$ of $L$ destructor extract (Allergon $\mathrm{AB}$, Engelhom, Sweden) and the non-commercial mixed flour extract $(\mathrm{BH})$. Eight sera were pooled for the $L$ destructor RAST pool (9.6\% isotope binding) and five sera for the flour RAST (7.0\% isotope binding). Extracts from the area environmental filters were assessed in parallel over the same concentration range. The RAST assays were completed and percentage binding of the ${ }^{125} I$ anti-IgE was compared with that of the relevant unabsorbed serum pool.

\section{RAST INHIBITION ANALYSIS}

A logit transformation, $\log _{\mathrm{e}}(\mathrm{p} /[1-\mathrm{p}])$, of the percentage inhibition of the $L$ destructor and mixed flour (BH) RAST assays was plotted against log concentration of inhibitor. The regression lines obtained were compared by analysis of covariance and a common slope fitted where it was possible, as described previously. ${ }^{9}$

\section{Environmental mesurement AREA SAMPLING}

A Staplex high volume air sampler was used to sample the atmosphere in the mixing area and flour room of the main bakery, the confectionery bakery, and the hot plate bakery to assess which aeroallergens were present. This sampler maintains an airflow of $1.4 \mathrm{~m}^{3} / \mathrm{min}$ and is estimated to retain $95 \%$ of particles $>0.3 \mu \mathrm{m}$ on a fibreglass filter sheet $22.7 \mathrm{~cm}$ by $17 \cdot 7 \mathrm{~cm}$.

\section{AEROALLERGEN ELUTION AND MEASUREMENT OF AREA} SAMPLE FILTERS

Soluble material was eluted from 11 filter sheets by descending chromatography with a borate buffer (sodium citrate $0.034 \mathrm{~mol} / \mathrm{l}$, sodium borate $0.0325 \mathrm{~mol} / 1$ in $0.16 \mathrm{~mol} / 1$ sodium chloride, $\mathrm{pH} 8 \cdot 2$ ). The eluates collected after eight hours were dialysed against distilled water and lyophilised. Mixed flour $(\mathrm{BH})$ and $L$ destructor allergen concentration in the eluates was estimated by RAST inhibition assays. Only seven of the 11 filter eluates were analysed for $L$ destructor content due to limited supplies of $L$ destructor extract. 


\section{Determination of personal exposure concen- trations}

Personal air samples were collected from the breathing zone of workers to estimate dust and aeroallergen concentrations. Closed face $37 \mathrm{~mm}$ diameter polystyrene aerosol monitors (Millipore, Harrow) housing preweighed polycarbonate membrane filters $(0.8 \mu \mathrm{m}$ pore size; Nucleopore, Sterilin, Hounslow) were used. These were connected to portable battery operated vacuum pumps (L2SF, Rotheroe and Mitchell, Aylesbury) sampling at an air flow rate of $21 / \mathrm{min}$.

\section{EXPOSURE RANKING}

Exposure ranking was assessed independently from the measurement of dust concentration. Each employment category was ranked on a scale of 0 (low) to 10 (high) for perceived dustiness by the bakery manager in consultation with an occupational physician from the baking industry. We divided exposure into high ( $\geqslant$ rank 6 ) and low ( $<$ rank 6$)$. Within each rank one or more employees wore sampling devices for periods of 1.5 to seven hours. Seventy nine personal dust samples were collected to provide gravimetric measurements of total airborne dust but only 55 of the filters were suitable for analysis of flour allergen content.

\section{AEROALLERGEN ELUTION AND MEASUREMENT OF PERSONAL AIR SAMPLE FILTERS}

The filters were eluted with two successive additions of $1 \mathrm{ml} 0.1 \mathrm{M} \mathrm{NH}_{4} \mathrm{CO}_{3}(\mathrm{pH} \mathrm{7.0})$ in a syringe as described by Edwards et al ${ }^{11}$ but without Tween 20 in the eluting buffer. The supernatants of the eluates were filtered through a $0.2 \mu \mathrm{m}$ filter (Sartorius, UK), dialysed overnight against distilled water, and lyophilised. Mixed flour (BH) concentration [flour] was again estimated by RAST inhibition. Results were interpolated from the logit transformed mixed flour standard curve and the flour aeroallergen concentration of each filter calculated as:

Flour aeroallergen $\left(\mu \mathrm{g} / \mathrm{m}^{3}\right)=$

[flour] $\times$ Reconstituted volume of filter eluate $(\mathrm{ml})$ volume of air sampled $\left(\mathrm{m}^{3}\right)$

\section{STATISTICAL PROCEDURES}

The relation of potential explanatory variables to skin test and RAST responses in the bakery and salt packing workers was examined by logistic regression. The independent explanatory variables included in the analyses were age, sex, current smoker, ever smoked, atopic state, years worked in the bakery, and exposure rank.

\section{Results}

SKIN PRICK TESTS

Forty two per cent of bakery workers were atopic, $6 \%$ had a positive skin prick test to mixed flour ( 5105 , Bencard), and $33 \%$ were positive to at least one of four storage mites (fig 1). A similar $41.5 \%$ of the salt packing workers were atopic, $33.8 \%$ had a positive skin prick test to storage mites, and $1.5 \%$ to flour. When salt packing workers with previous occupational exposure to flour were excluded (11 workers) $40.7 \%$ were atopic, $29.6 \%$ were positive to storage mites, and none responded to mixed flour.

Logistic regression analysis had shown that ever having worked in a bakery job ranked six or above was associated with a skin prick test response to one

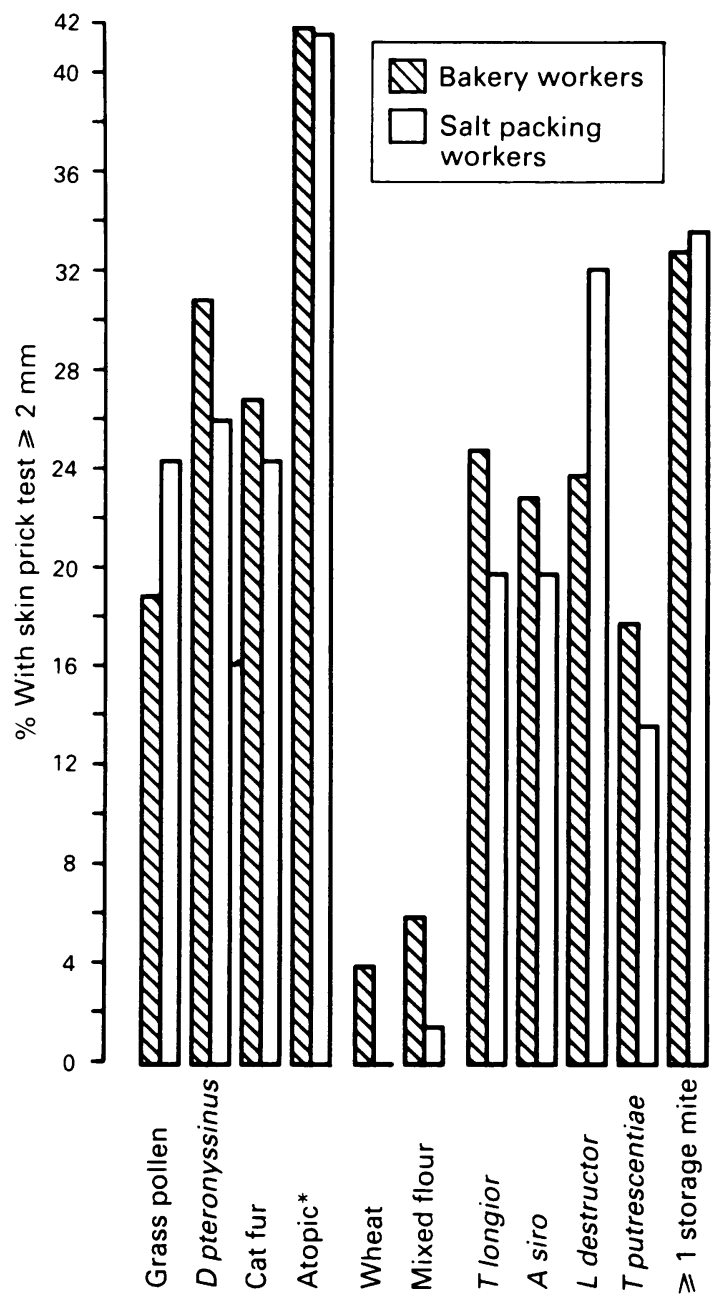

Figure 1 Skin prick test responses to common and bakery allergens in 251 bakery workers and 65 salt packing workers. Atopic ${ }^{\star}=$ positive skin prick test to $\geqslant 1$ of $D$ pteronyssinus, grass pollen, and cat fur. 

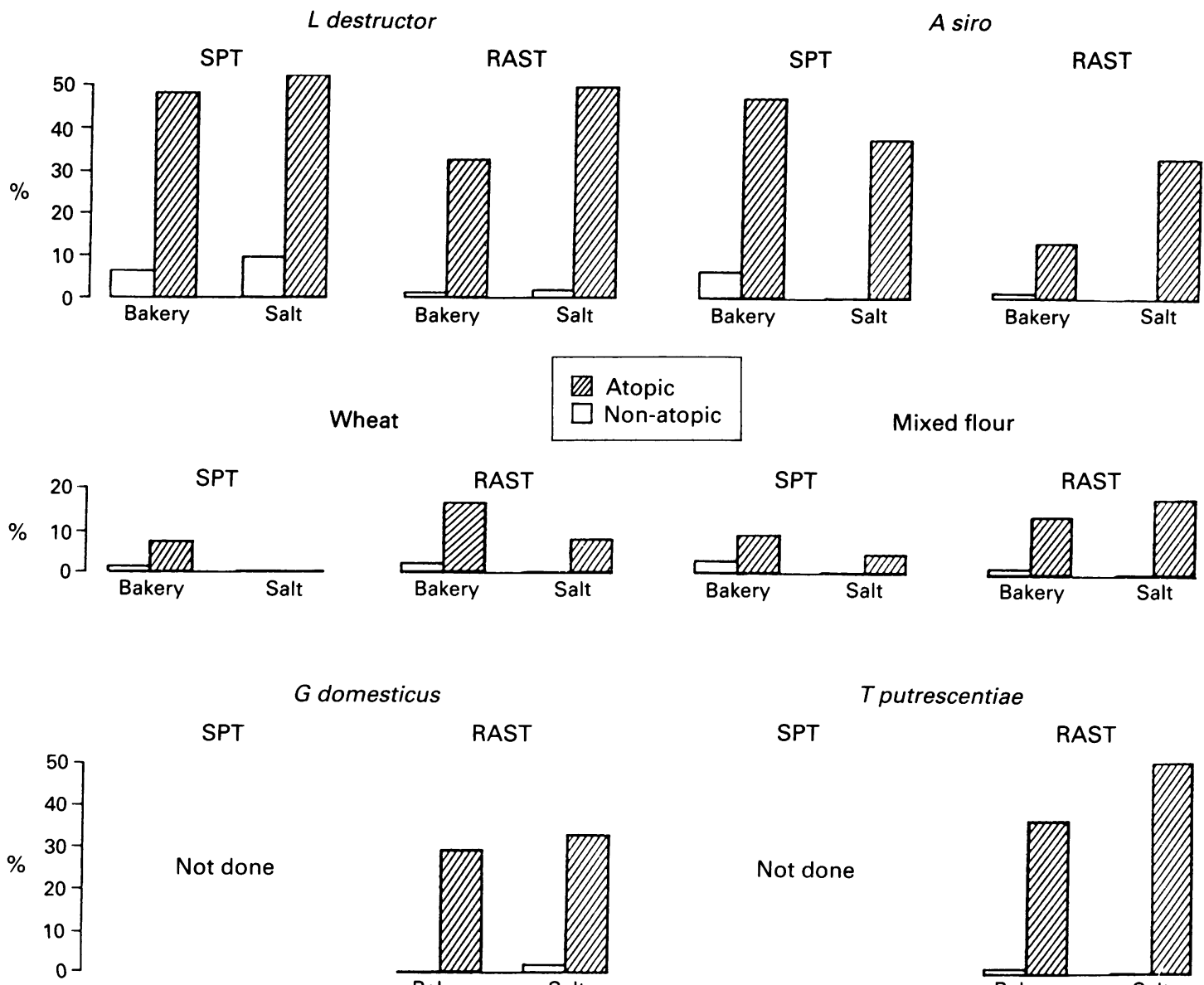

G domesticus

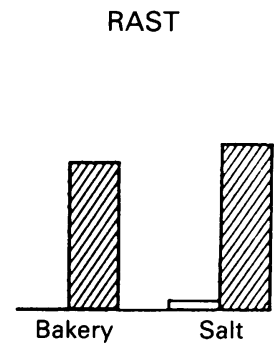

Tputrescentiae

SPT

RAST

Not done

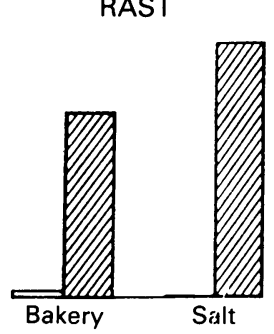

Figure 2 RAST and skin prick test (SPT) responses to bakery allergens in the bakery workers and salt packing workers based on atopy.

or more of the bakery allergens flour, wheat, and storage mites. ${ }^{8}$ Atopy was the most significant explanatory variable for a positive skin prick test to bakery antigens in the bakery workers and for all the antigens except wheat in the salt packing workers. This was most pronounced in the storage mites $L$ destructor, $A$ siro, and $T$ longior as shown in fig 2 where the atopic workers have been divided from the non-atopic workers for each bakery antigen. Of those who were atopic between 37 and $52 \%$ had a positive skin prick test to storage mites, whereas only $6-7 \%$ of the non-atopic workers had these responses. The analysis was not made for $T$ putrescentiae or $G$ domesticus as the salt packing workers did not have skin prick tests made with the same source of antigens as the bakery workers.

RAST

A greater proportion of the salt packing workers than the bakery workers had a positive RAST ( $\geqslant 0.35$ PRU) to $D$ pteronyssinus and to the four storage mites tested (fig 3). The most frequent response to a storage mite was to $L$ destructor in both groups. The prevalence of a positive RAST response to wheat and to flour in the bakery workers was not high $(3.3 \%$, $3.3 \%$ ) although greater than in the control group $(1.5 \%, 3.0 \%)$. As with skin prick test, atopy was the most significant explanatory variable for a positive RAST response to storage mites, wheat, and flour in both groups of workers (fig 2). Between 29 and 50\% of those who were atopic had a positive RAST to the various storage mites.

\section{AEROALLERGEN MEASUREMENT}

All the eluates from the 11 area filters inhibited the mixed flour RAST in a dose dependent fashion (fig 4 (left), seven filters shown). The solid squares represent the standard flour antigen dose response 


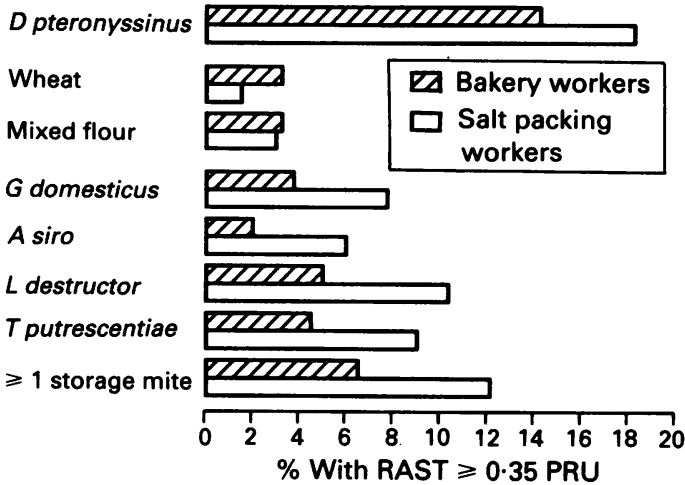

Figure $3 R A S T$ responses to $D$ pteronyssinus and bakery allergens in 244 bakery workers and 66 salt packing workers.

curve with which the filter eluates were compared. Logit transformation of the data showed that the slopes of all the filter eluates were not significantly different from the slope of flour, indicating immunological identity between the air samples and flour allergen. Lines with a common slope could therefore be fitted.

Of the seven bakery filter eluates analysed for $L$ destructor content, two showed no inhibition of the $L$ destructor RAST (not shown). The solid squares

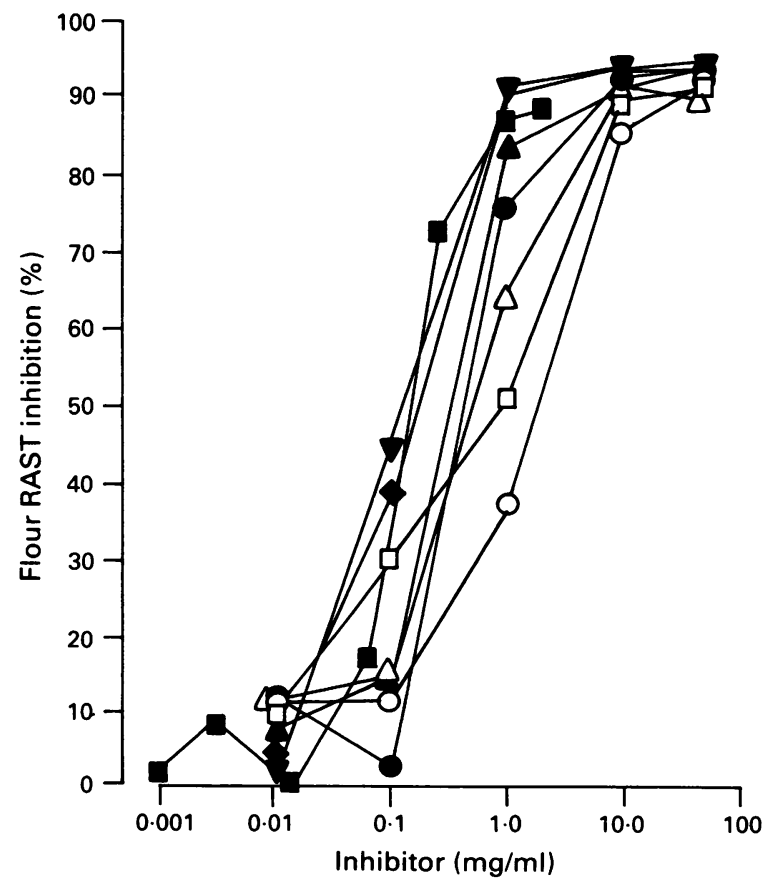

Number of employees participating in the study and results of dust sampling by exposure rank

\begin{tabular}{|c|c|c|c|c|}
\hline \multirow[b]{3}{*}{ Rank } & \multirow{3}{*}{$\begin{array}{l}\text { Total } \\
\text { employees }\end{array}$} & \multicolumn{3}{|c|}{ Dust sampling } \\
\hline & & \multirow{2}{*}{$\begin{array}{l}\text { No of } \\
\text { samples } \\
\text { tested }\end{array}$} & \multicolumn{2}{|c|}{ Total dust ( $\left.\mathrm{mg} / \mathrm{m}^{3}\right)$} \\
\hline & & & Range & Geometric mean \\
\hline $\begin{array}{r}0 \\
1 \\
2 \\
3 \\
4 \\
5 \\
6 \\
7 \\
8 \\
9 \\
10\end{array}$ & $\begin{array}{r}52 \\
23 \\
84 \\
7 \\
29 \\
20 \\
29 \\
57 \\
9 \\
2 \\
6\end{array}$ & $\begin{array}{l}1 \\
2 \\
23 \\
0 \\
5 \\
1 \\
16 \\
12 \\
10 \\
2 \\
7\end{array}$ & $\begin{array}{l}0.18 \\
0.00-0.08 \\
0.00-3.65 \\
\overline{0.01-0.99} \\
2.97 \\
0.00-37.57 \\
0.01-16.80 \\
0.59-14.10 \\
9.97-12.05 \\
1.84-13.03\end{array}$ & $\begin{array}{c}0.18 \\
0.11 \\
0.34 \\
- \\
0.24 \\
2.97 \\
1.73 \\
2.13 \\
2.69 \\
11.0 \\
6.59\end{array}$ \\
\hline Total & 318 & 79 & - & - \\
\hline
\end{tabular}

represent the standard $L$ destructor dose response curve but only one filter $(\Delta)$ showed any evidence of a dose response curve of inhibition, suggesting the presence of $L$ destructor in the air (fig 4 right).

PERSONAL EXPOSURE MEASUREMENTS

The table shows the results of the gravimetric measurements on the 79 personal dust samples. (from Musk et $a l^{8}$ table 1). Although there was a wide scatter of results, the geometric mean of the dust

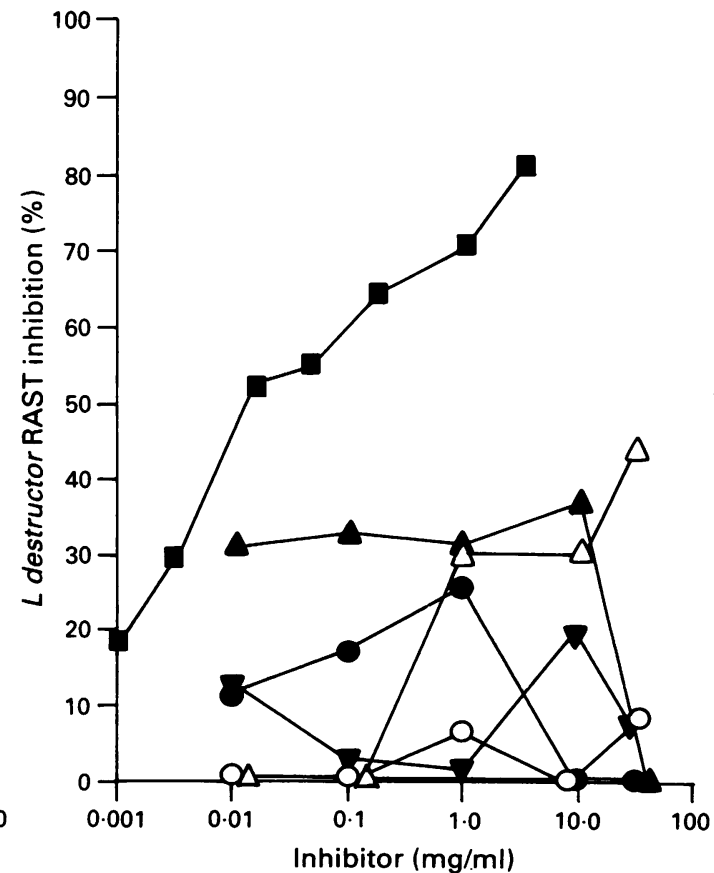

Figure 4 RAST inhibition analysis of Staplex high volume air sample filters from different areas in the bakery. Left, flour RAST inhibition; seven filters shown. $=$ flour antigen.

$R$ ight, $L$ destructor $R A S T$ inhibition (two filters (not shown) did not inhibit). $\square=L$ destructor antigen. 


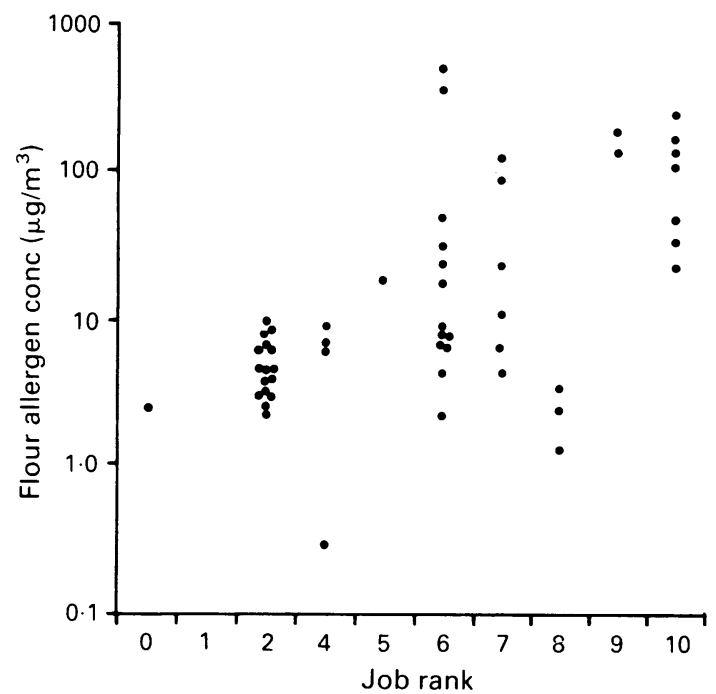

Figure 5 Analysis of 55 personal bakery air sample filters. Flour allergen concentration compared with job rank assessed by perceived dustiness where 0 is low and 10 is high.

concentration increased with increasing rank. Fifty five of the filter eluates were suitable for estimation of flour allergen content and concentration of allergen $\geqslant 10 \mu \mathrm{g} / \mathrm{m}^{3}$ was found in 19 of 32 filters from workers in jobs ranked $\geqslant 6$, but in only one of 23 filters from workers in jobs less than rank 6 (fig 5). No attempt was made to measure $L$ destructor antigen in the personal filter eluates because of the finding of low concentrations of this antigen in the area filter eluates.

Figure 6 shows the relation between total dust concentration and flour allergen concentration in $\mathbf{5 3}$ personal air samples. A linear relation exists in the samples above $5 \mathrm{mg}$ of dust.

\section{Discussion}

In this study we have investigated whether storage mite antigen is important in the development of asthma in bakery workers. We compared the immune responses of salt packing workers without exposure to flour with those of the bakery workers and found a similar prevalence of positive skin prick tests to storage mites and a higher percentage with a positive RAST. Forty two per cent of bakery and salt packing workers were atopic and atopy was found to be the major explanatory variable for a positive skin prick response in both groups, especially to storage mites. These results imply that storage mites are widely distributed in the environment and sensitisation to them is not increased among flour handlers.

Several studies have shown that storage mites are common sensitisers in agricultural workers including farmers in Scotland, ${ }^{12}$ Sweden, ${ }^{13}$ Finland, ${ }^{14}$ and the United Kingdom. ${ }^{15}$ Storage mites are not only a rural problem. Mites are very sensitive to dry environments, preferring $90 \%$ relative humidity and a temperature between $25-30{ }^{\circ} \mathrm{C}$. As long ago as 1967 Spieksma and Spieksma-Boezeman ${ }^{16}$ suggested that storage mite allergy may be important in countries with a damp climate. In 1979 Wraith et al ${ }^{17}$ showed an association between dampness in the dwelling and a positive skin prick test to storage mites and Warren et $a l^{18}$ and Korsgaard et $a l^{19}$ both reported significant skin test responses to storage mites in patients at their clinics. Recently Iversen $e t a^{20}$ suggested that allergy to storage mites in the farmers he studied might be partly attributable to damp housing conditions and indoor exposure to storage mites.

A high prevalence of allergic immune responses to storage mites in bakery workers may, therefore, not be due to an occupational cause, and we have found an equally high prevalence in the salt packing workers not exposed to flour. We conclude that storage mites are not of special significance in allergic responses in bakery workers.

We used environmental sampling to see if, as well as flour, the storage mite aeroallergen content was significant. As all of the filter eluates showed immunological identity with the flour standard antigen and only one of seven showed a dose response curve with $L$ destructor, the allergen in the bakery atmosphere appears to be predominantly flour and not storage mite.

Personal airborne dust samples were obtained from all work areas of the bakery and the content of flour allergen measured. Job rank based on perceived dustiness, which had been shown to be related to total dust, ${ }^{8}$ was found in turn to be proportional to the concentration of flour allergen measured in the air. Figure 6 suggests a linear relation in the samples containing total dust concentrations of more than $5 \mathrm{mg} / \mathrm{m}^{3}$ whereas there was little variation in flour aeroallergen concentration in samples with less dust. It is possible that, in this bakery, variation in total

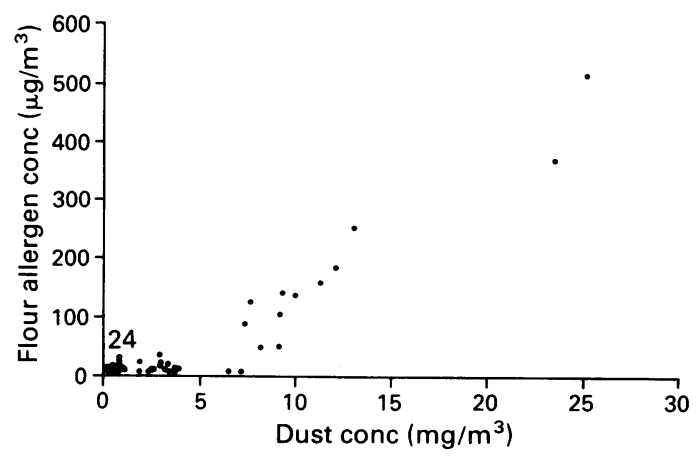

Figure 6 Relation between gravimetric dust measurements and flour allergen concentration in 53 personal bakery air sample filters. 
dust concentrations of less than $5 \mathrm{mg} / \mathrm{m}^{3}$ is explained by varying concentrations of non-flour dust. Logistic regression analysis had shown that ever having worked in a high dust exposure category ( $\geqslant$ rank 6 ) was associated with both a skin prick test response to one or more bakery allergens and also to airway hyperresponsiveness $\left(\mathrm{PD}_{20}\right.$ to methacholine $\leqslant 30 \mu \mathrm{mol}){ }^{8}{ }^{8}$ These findings suggest that the development of immunological and airway responsiveness to inhaled flour dust is increased in those exposed to higher concentrations of airborne flour allergen. Allergy to storage mites appears to be due to environmental and not occupational exposure.

The help of Drs B J Graneek, G Crook, J H Darbyshire, P Fitzharris, Miss E R Hawkins, and Mr N M Farrer in the conduct of the studies is gratefully acknowledged. Exposure rankings were determined by Dr P Harries and Mr B Tolley. We also thank Mr D Lowson and Miss D A Johnson for help in statistical analysis and Mrs A Addison for her secretarial assistance in the preparation of this paper.

1 Herxheimer $H$. The skin sensitivity to flour of bakers' apprentices. Acta Allergolica 1973;28:42-9.

2 Hendrick DJ, Davies RJ, Pepys J. Bakers' asthma. Clinical Allergy 1976;6:241-50.

3 Thiel H, Ulmer WT. Bakers' asthma: development and possibility for treatment. Chest 1980;78 (suppl):400-5.

4 Block G, Kijek K, Chan H, Tse KS, Chan-Yeung M. Pathogenic mechanisms in bakers' asthma. Am Rev Respir Dis 1982;125 (suppl):74.

5 Sutton R, Skerritt JH, Baldo BA, Wrigley CW. The diversity of allergens involved in bakers' asthma. Clinical Allergy 1984;14:93-107.

6 Klaustermeyer WB, Bardana EJ Jr, Hale FC. Pulmonary hypersensitivity to Alternaria and Aspergillus in bakers' asthma. Clinical Allergy 1977;7:227-33.
7 Blainey $\mathrm{AD}$, Topping $\mathrm{MD}$, Ollier S, Davies RJ. Allergic respiratory disease in grain workers: The role of storage mites. $J$ Allergy Clin Immunol 1989;84:296-303.

8 Musk AW, Venables KM, Crook B, et al. Respiratory symptoms, lung function, and sensitisation to flour in a British bakery. Br J Ind Med 1989;46:636-42.

9 Tee RD, Gordon DJ, Lacey J, Nunn AJ, Brown M, Newman Taylor AJ. Occupational allergy to the common house fly (Musca domestica): use of immunologic response to identify aumospheric allergen. J Allergy Clin Immunol 1985;76: 826-31.

10 Tee RD, Gordon DJ, van Hage Hamsten M, Gordon S, Nunn AJ, Johansson SGO, Newman Taylor AJ. Comparison of allergenic responses to dust mites in UK bakery workers and Swedish farmers. Clin Exp Allergy (in press).

11 Edwards RG, Beeson MF, Dewdney JM. Laboratory animal allergy: the measurement of airborne urinary allergens and the effects of different environmental conditions. Lab Anim 1983;17:235-9.

12 Cuthbert OD, Jeffrey IG, McNeill HB, Wood J, Topping MD. Barn allergy among Scottish farmers. Clinical Allergy 1984;14:197-206.

13 van Hage-Hamsten $M$, Johansson SGO, Hoglund S, Tull P, Wiren A, Zetterstrom $O$. Storage mite allergy is common in a farming population. Clinical Allergy 1985;15:555-64.

14 Terho EO, Husman $K$, Vohlonen I, Rautalahti $M$, Tukianen $H$. Allergy to storage mites or cow dander as a cause of rhinitis among Finnish dairy farmers. Allergy 1985;40:23-6.

15 Blainey AD, Topping MD, Oilier S, Davies RJ. Respiratory symptoms in arable farmers: the role of storage mites. Thorax 1988;43:697-702.

16 Spieksma FThM, Spieksma-Boezeman MA. The mite fauna of house dust with particular reference to the house-dust mite Dermatophagoides pteronyssinus. Acarologia 1967;9:226-41.

17 Wraith DG, Cunningham AM, Seymour WM. The role and allergenic importance of storage mites in house dust and other environments. Clinical Allergy 1979;9:545-61.

18 Warren CPW, Holford-Strevens V, Sinha RN. Sensitisation in a grain handler to the storage mite Lepidoglyphus destructor (Schrank). Ann Allergy 1983;50:30-3.

19 Korsgaard J, Dahl R, Iversen M, Hallas T. Storage mites as a cause of bronchial asthma in Denmark. Allergol Immunopathol (Madr) 1985;13:143-9.

20 Iversen M, Korsgaard J, Hallas T, Dahl R. Mite allergy and exposure to storage mites and house dust mites in farmers. Clin Exp Allergy 1990;20:211-9.

Accepted 4 November 1991 